\title{
Nutrients Leaching from Tillage Soil Amended with Wheat Straw Biochar Influenced by Fertiliser Type
}

\author{
Cheng Huang ${ }^{1,2,3}$, Xiuyun Sun ${ }^{2}$, Lianjun Wang ${ }^{2}$, Paul Storer ${ }^{4} \mathbb{D}$, Kadambot H. M. Siddique ${ }^{1 \mathbb{D}}$ \\ and Zakaria M. Solaiman $1, *$ (D)
}

1 The UWA Institute of Agriculture, and UWA School of Agriculture and Environment, The University of Western Australia, Perth, WA 6009, Australia; chenghuang@just.edu.cn (C.H.); kadambot.siddique@uwa.edu.au (K.H.M.S.)

2 Jiangsu Key Laboratory of Chemical Pollution Control and Resources Reuse, School of Environmental and Biological Engineering, Nanjing University of Science and Technology, Nanjing 210094, China; sunxyun@njust.edu.cn (X.S.); wanglj@njust.edu.cn (L.W.)

3 School of Environmental and Chemical Engineering, Jiangsu University of Science and Technology, Zhenjiang 212100, China

4 Troforte Innovations Pty Ltd., Wangara, WA 6065, Australia; soilmicrobes@bigpond.com

* Correspondence: zakaria.solaiman@uwa.edu.au; Tel.: +61-8-6488-7463

Citation: Huang, C.; Sun, X.; Wang, L.; Storer, P.; Siddique, K.H.M.; Solaiman, Z.M. Nutrients Leaching from Tillage Soil Amended with Wheat Straw Biochar Influenced by Fertiliser Type. Agriculture 2021, 11, 1132. https://doi.org/10.3390/ agriculture11111132

Academic Editor: Mumtaz Cheema

Received: 25 September 2021

Accepted: 8 November 2021

Published: 11 November 2021

Publisher's Note: MDPI stays neutral with regard to jurisdictional claims in published maps and institutional affiliations.

Copyright: (c) 2021 by the authors. Licensee MDPI, Basel, Switzerland. This article is an open access article distributed under the terms and conditions of the Creative Commons Attribution (CC BY) license (https:// creativecommons.org/licenses/by/ $4.0 /)$.

\begin{abstract}
The co-application of biochar and fertiliser has emerged as a strategy for improving soil quality and crop growth; however, the impact of the type of fertiliser added with biochar to the soil on leaching and retention of nutrients is not well studied. In this study, a leaching experiment was undertaken using a series of column lysimeters incorporating a wheat straw biochar (WSB) and two fertiliser types-chemical fertiliser (CF), or rock mineral fertiliser (MF). The results showed that CF and MF leached a similar amount of $\mathrm{NH}_{4}{ }^{+}$with or without $\mathrm{WSB}$, but the $\mathrm{NO}_{3}{ }^{-}$leaching occurred from CF-treated soil which was decreased by CF + WSB application. In contrast, $\mathrm{NO}_{3}{ }^{-}$leaching was not affected by WSB in MF-treated soil. Both CF and MF with or without WSB increased the cumulative leaching of $\mathrm{P}$ and $\mathrm{K}$. Nevertheless, WSB application increased soil P and K contents after leaching, which was attributed to intrinsic nutrient release from biochar. Shoot growth and $\mathrm{P}$ and $\mathrm{K}$ uptake also increased with biochar amendment, whereas root growth and $\mathrm{N}$ uptake did not change. Therefore, the results highlight that biochar addition can improve nutrient retention and plant growth by reducing nutrient leaching, mainly dependent on biochar and fertiliser type combination used. It suggests that the adsorption properties of biochar for nutrient retention and subsequent release need to know before their broad application to soils as amendments.
\end{abstract}

Keywords: wheat straw biochar; fertiliser; nutrients leaching; nutrient retention; wheat growth

\section{Introduction}

With the rapid population growth, cultivated land scarcity and increasingly rigorous food safety regulations, crop production needs to be improved to mitigate the food crisis. Fertiliser is commonly incorporated into soil to provide necessary macronutrients, such as nitrogen $(\mathrm{N})$, phosphorus $(\mathrm{P})$ and potassium $(\mathrm{K})$, for plant growth [1]. However, excessive long-term fertilisation can cause soil deterioration [2], groundwater pollution [3,4] and eutrophication [5]. Moreover, fertiliser use efficiency is relatively low due to the loss of nutrients through leaching, running off and evaporation. Thus, an efficient and environmentally benign fertilisation strategy is needed.

Application of biochar has been proposed as amendment practice to improve soil fertility and quality as it is a carbon-rich material derived from waste materials such as animal manure [6,7], crop residues [8] and sewage sludge [9,10]. Biochar increases soil carbon (C) sequestration, soil water holding capacity (WHC) and reduces the mobility of toxic heavy metals, pesticides and other organic pollutants, as is well reported [11]. Several 
studies have presented the positive effect of biochar on soil microbial and mycorrhizal activity, which influences nutrient availability to plants [12,13]. Furthermore, biochar can adsorb nutrients into its large surface area, potentially contributing to retention and recycling. Consequently, the application of biochar combined with fertilisers could simultaneously improve crop yield and fertiliser use efficiency [14]. Ding et al. [15] reported that wood-derived biochar adsorbed ammonium ions predominantly by cation exchange and reduced nitrate and organic $C$ leaching in tillage soils amended with pig manure. Similar observations have been observed with other biochars in fertilised soils [16-18].

The effects of biochar amendment on enhancing nutrient retention have been wellstudied, but the impact on nutrient leaching is inconsistent. Iqbal et al. [19] reported that co-composted biochar application did not significantly reduce $\mathrm{NO}_{3}{ }^{-}, \mathrm{P}$ or organic $\mathrm{C}$ leaching, relative to the compost only treatment. Madiba et al. [20] revealed that biochar improved P uptake and leaching, indicating that biochar application was not a mitigation strategy for decreasing P leaching in sandy soils. These contradictory results suggest that the nutrient retention capability of biochar from fertiliser varies depending on the type of fertiliser used and the characteristics of biochar and amended soil properties. Hence, a better understanding of the influence of biochar addition on nutrient leaching and the physical and chemical properties of amended soils is needed.

Only a few experiments have examined the effect of biochar on nutrient leaching in fertilised soils, particularly comparing different types of fertiliser. For example, Schulz and Glaser [21] demonstrated that the addition of biochar combined with organic fertiliser had synergistic effects on soil fertility, relative to biochar combined with NPK fertiliser. Zheng et al. [22] reported a significant reduction in $\mathrm{NH}_{4}{ }^{+}-\mathrm{N}$ leaching from the soil with the addition of biochar combined with $\mathrm{NO}_{3}{ }^{-}-\mathrm{N}$ fertiliser, but not with $\mathrm{NH}_{4}{ }^{+}-\mathrm{N}$ fertiliser. The research gap, however, remains for the interactions and the mechanisms that affect soil nutrients when biochar is used as a soil amendment with different types of fertiliser. There is no legislation of the biochar agricultural use in Australia, but there is a draft user guideline published by ANZ Biochar Initiative.

In this study, we hypothesised that biochar application to fertilised soils decreases nutrient leaching and increases nutrient retention, which mostly depends on the types of fertiliser used. This study aimed to comprehensively evaluate the potential of biochar application combined with types of fertiliser on nutrient leaching and retention and investigate their effects on plant growth and nutrient uptake after the leaching events.

\section{Materials and Methods}

\subsection{Biochar, Soil and Fertilisers}

The biochar used in this experiment were produced from wheat straw at $550{ }^{\circ} \mathrm{C}$ (Pacific Pyrolysis Pty Ltd., Somersby, Australia) using Slow Pyrolysis Technology (C4H4). Basic characteristics of biochars are presented in Table 1. The $\mathrm{pH}$ and EC of biochar were measured in water at 1:5 $(w / v)$ ratios. A subsample of biochar was finely ground before analyses of total carbon and total nitrogen concentrations with dry combustion using an elemental analyser (vario MACRO CNS; Elementar, Germany). Other biochar properties (CEC, EC-; P\%; K\%) were measured using standard methods [23]. A representative soil from the Western Australian wheatbelt $(0-10 \mathrm{~cm}$ surface layer) was collected from Hayden, Western Australia. The basic characteristics and nutrient concentrations of the soil were analysed using standard methods, as presented in Table 1. The chemical fertiliser (CF) was procured from Summit Fertilizers, Kwinana Beach, Western Australia, and the rock mineral fertiliser (MF) from Troforte Innovations Pty Ltd, Wangara, Western Australia. The MF consisted of a proprietary combination of various fine mineral ores, including micas, alkali feldspars, soft rock phosphate, gypsum, dolomite, basalt, granite and crystalline silica, which are blended with sulphate of ammonia and sulphate of potash, manganese sulphate, copper sulphate and zinc sulphate (Table 1). 
Table 1. Physical and chemical properties of soil and amendments used in this experiment. $\mathrm{CF}=$ chemical fertiliser; $\mathrm{MF}=$ mineral fertiliser; WSB $=$ wheat straw biochar.

\begin{tabular}{|c|c|c|c|c|c|c|c|c|}
\hline Characteristics & Soil & Characteristics & Soil & Characteristics & $\mathrm{CF}$ & MF & Characteristics & WSB \\
\hline Bulk density $\left(\mathrm{g} / \mathrm{cm}^{3}\right)$ & 1.4 & $\mathrm{NH}_{4}-\mathrm{N}(\mathrm{mg} / \mathrm{kg})$ & 5.9 & $\mathrm{~N}(\%)$ & 10.2 & 10.0 & $\mathrm{pH}\left(\mathrm{H}_{2} 0\right)$ & 9.0 \\
\hline Clay $(\%)$ & 5.0 & $\mathrm{NO}_{3}-\mathrm{N}(\mathrm{mg} / \mathrm{kg})$ & 27.9 & $\mathrm{P}(\%)$ & 13.1 & 7.5 & $\mathrm{C}(\%)$ & 56.6 \\
\hline Silt (\%) & 2.6 & Colwell P (mg/kg) & 73.8 & $\mathrm{~K}(\%)$ & 12.0 & 4.5 & CEC (me/100 gC) & 30.4 \\
\hline Sand $(\%)$ & 92.3 & Colwell K (mg/kg) & 58.9 & $\mathrm{~S}(\%)$ & 7.2 & 5.0 & $\mathrm{EC}(\mathrm{mS} / \mathrm{cm})$ & 7.7 \\
\hline $\mathrm{pH}\left(\mathrm{H}_{2} \mathrm{O}\right)$ & 5.4 & & & $\mathrm{Cu}(\%)$ & 0.07 & 0.04 & Pore volume $\left(\mathrm{m}^{2} / \mathrm{g}\right)$ & 190.1 \\
\hline $\mathrm{EC}(\mathrm{mS} / \mathrm{m})$ & 207.2 & & & $\mathrm{Zn}(\%)$ & 0.13 & 0.04 & $\mathrm{~N}(\%)$ & 0.8 \\
\hline C (\%) & 1.15 & & & & & & $\mathrm{P}(\%)$ & 3.4 \\
\hline $\mathrm{N}(\%)$ & 0.08 & & & & & & $\mathrm{~K}(\%)$ & 17.8 \\
\hline
\end{tabular}

\subsection{Lysimeter Experiment}

An experiment using lysimeter was carried out to investigate the effect of biochar on nutrient leaching from fertilised soil according to a modified method of Madiba et al. (2016). The lysimeters were constructed from polyvinyl chloride (PVC) tubes with dimensions of $10.5 \mathrm{~cm}$ diameter and $30 \mathrm{~cm}$ depth. Each lysimeter was fitted with a plastic tube at the bottom for collecting leachate. The soil was sieved through a $2 \mathrm{~mm}$ mesh and subjected to one of six fertiliser and/or biochar treatments prior to filling the lysimeters: (i) control (nil application), (ii) water-soluble chemical fertiliser (CF) at $10 \mathrm{~kg} \mathrm{~N} /$ ha (equivalent to $1.2 \mathrm{~g} / \mathrm{pot}$ ), (iii) slow-release rock mineral fertiliser (MF) at $10 \mathrm{~kg} \mathrm{~N} / \mathrm{ha}$ (equal to $1.2 \mathrm{~g} / \mathrm{pot}$ ), (iv) wheat straw biochar (WSB) applied at a rate equivalent to $2 \%$ (64 g biochar/lysimeter), (v) chemical fertiliser mixed with biochar (CF + WSB), and (vi) rock mineral fertiliser mixed with biochar (MF + WSB). The experiment comprised 24 lysimeters with four replication per treatment. Each lysimeter was filled with $3.2 \mathrm{~kg}$ of respective soil.

Before commencing the lysimeter experiment, approximately $250 \mathrm{~mL}$ of deionised water were added to the soil in each lysimeter to adjust the moisture content to $80 \%$ WHC. The loss of water through evaporation was compensated for maintaining $80 \%$ WHC by adding deionised (DI) water every second day by weighing. Each lysimeter was slowly leached with $500 \mathrm{~mL}$ DI water weekly during the leaching period. The leachate from each column was then collected from the outlet at the bottom of the lysimeter, and the total volume of leachate was measured immediately. After the experiment ended, soil samples were taken from each column for subsequent assay.

\subsection{Pot Experiment}

A pot experiment under laboratory conditions was conducted to assess the afterleaching residual effect of biochar application on nutrient uptake and plant growth. After the lysimeter experiment ended, each lysimeter was deconstructed, and $2.2 \mathrm{~kg}$ of the soil mixture was added to a plastic pot. Wheat (Triticum aestivum L.) crop was selected as it is the main crop grown in Western Australia. Six seeds of wheat were sown into each pot and thinned to three seedlings after emergence. The pots were DI watered daily to $80 \%$ WHC and harvested at anthesis stage of growth. Shoots and roots were oven-dried at $60{ }^{\circ} \mathrm{C}$ for at least $72 \mathrm{~h}$ and weighed. Oven-dried shoots were ground finely and digested with $\mathrm{HNO}_{3} / \mathrm{HClO}_{4}$ to measure nutrient concentrations. The total $\mathrm{N}, \mathrm{P}$ and $\mathrm{K}$ in the digest were measured with an elemental analyser (Vario MACRO CNS; Elementar, Germany) for $\mathrm{N}$ and inductively coupled plasma-atomic emission spectrometry (ICP-AES) for P and K. Nutrient uptake was calculated by multiplying individual nutrient concentration by shoot dry weight.

\subsection{Leachate and Soil Analysis of the Lysimeter Experiment}

Ammonium $\left(\mathrm{NH}_{4}{ }^{+}\right)$and nitrate $\left(\mathrm{NO}_{3}{ }^{-}\right)$concentration in the leachates were measured by extracting with $0.5 \mathrm{M} \mathrm{K}_{2} \mathrm{SO}_{4}$ and analysing the extract in a spectrophotometer for $\mathrm{NH}_{4}{ }^{+}$[24] and $\mathrm{NO}_{3}{ }^{-}$[25]. Phosphorus in leachate was determined using the molybdenum blue method [26]. The K content was analysed with a flame photometer. 
Soil samples were taken from each lysimeter at the end of leaching period and extracted by shaking with $0.5 \mathrm{M} \mathrm{K}_{2} \mathrm{SO}_{4}$ for $2 \mathrm{~h}$ to determine the $\mathrm{NH}_{4}{ }^{+}$and $\mathrm{NO}_{3}{ }^{-}$concentrations according to the methods above. Total $\mathrm{C}$ and $\mathrm{N}$ content of the soil was measured using an elemental analyser (Vario MACRO CNS; Elementar, Germany). The soil samples were digested with $\mathrm{HNO}_{3} / \mathrm{HCl}$, and then total $\mathrm{P}$ and $\mathrm{K}$ contents were measured by ICP-AES (Tables 2 and 3).

Table 2. Two-way ANOVA results of nutrients, $\mathrm{pH}, \mathrm{EC}$ and volume of leachate. ${ }^{*}$ and ${ }^{* * *}$ are significant at. $p<0.05$ and $p<0.001$, respectively; $\mathrm{ns}=$ not significant.

\begin{tabular}{cccccccc}
\hline Main and Interaction Effects & $\mathbf{N H}_{\mathbf{4}}$ & $\mathrm{NO}_{3}$ & $\mathbf{P}$ & $\mathbf{K}$ & $\mathbf{p H}$ & EC & Leachate Volume \\
\hline Biochar & $0.050^{*}$ & $0.004^{* * *}$ & $<0.001^{* * *}$ & $<0.001^{* * *}$ & $<0.001^{* * *}$ & $<0.001^{* * *}$ & $<0.001^{* * *}$ \\
Fertiliser & $<0.001^{* * *}$ & $<0.001^{* * *}$ & $<0.001^{* * *}$ & $0.004^{* * *}$ & $0.013^{* * *}$ & $0.850 \mathrm{~ns}$ & $0.685 \mathrm{~ns}$ \\
Biochar $\times$ Fertiliser & $0.154 \mathrm{~ns}$ & $0.064_{\mathrm{ns}}$ & $0.245 \mathrm{~ns}$ & $<0.001^{* * *}$ & $0.098 \mathrm{~ns}$ & $<0.001^{* * *}$ & $0.353 \mathrm{~ns}$ \\
\hline
\end{tabular}

Table 3. Nutrient concentrations $(\mathrm{mg} / \mathrm{kg}$ ) retained in soils after leaching events for the fertilisers and biochar and their interactions. Values are shown as the mean \pm standard errors. Different letters indicate significant differences between treatments $(p<0.05)$.

\begin{tabular}{ccccccc}
\hline Treatment & $\mathbf{N H}_{4}{ }^{+}$ & $\mathbf{N O}_{3}{ }^{-}$ & Total N & Available P & Total P & Total K \\
\hline Control & $4.31 \pm 0.97 \mathrm{c}$ & $3.71 \pm 0.91 \mathrm{~b}$ & $609 \pm 35 \mathrm{~b}$ & $0.89 \pm 0.12 \mathrm{~d}$ & $157.0 \pm 0.4 \mathrm{c}$ & $246.3 \pm 17.8 \mathrm{~b}$ \\
$\mathrm{CF}$ & $10.45 \pm 1.70 \mathrm{~b}$ & $3.76 \pm 0.80 \mathrm{~b}$ & $580 \pm 13 \mathrm{~b}$ & $2.76 \pm 0.62 \mathrm{bc}$ & $199.6 \pm 9.1 \mathrm{bc}$ & $270.4 \pm 4.6 \mathrm{~b}$ \\
MF & $11.69 \pm 0.29 \mathrm{~b}$ & $3.40 \pm 0.45 \mathrm{~b}$ & $550 \pm 32 \mathrm{~b}$ & $2.20 \pm 0.22 \mathrm{c}$ & $179.3 \pm 15.7 \mathrm{c}$ & $282.4 \pm 38.0 \mathrm{~b}$ \\
WSB & $12.01 \pm 1.59 \mathrm{~b}$ & $4.56 \pm 1.63 \mathrm{a}$ & $1060 \pm 39 \mathrm{a}$ & $3.79 \pm 0.56 \mathrm{~b}$ & $271.2 \pm 2.6 \mathrm{a}$ & $639.6 \pm 23.0 \mathrm{a}$ \\
CF + WSB & $11.27 \pm 1.05 \mathrm{~b}$ & $3.30 \pm 0.34 \mathrm{~b}$ & $950 \pm 83 \mathrm{a}$ & $7.73 \pm 0.57 \mathrm{a}$ & $252.2 \pm 16.3 \mathrm{ab}$ & $549.9 \pm 7.8 \mathrm{a}$ \\
MF + WSB & $17.92 \pm 1.61 \mathrm{a}$ & $3.36 \pm 1.02 \mathrm{~b}$ & $1020 \pm 45 \mathrm{a}$ & $6.44 \pm 0.65 \mathrm{a}$ & $281.9 \pm 33.7 \mathrm{a}$ & $621.5 \pm 33.5 \mathrm{a}$ \\
\hline Biochar & $<0.001$ & 0.021 & $<0.001$ & $<0.001$ & $<0.001$ & $<0.154 \mathrm{~ns}$ \\
Fertiliser & $<0.001$ & $0.678 \mathrm{~ns}$ & $0.059 \mathrm{~ns}$ & $<0.001$ & 0.048 \\
Biochar $\times$ Fertiliser & $<0.001$ & $0.879 \mathrm{~ns}$ & $0.149 \mathrm{~ns}$ & $<0.001$ & $0.225 \mathrm{~ns}$ & $0.078 \mathrm{~ns}$ \\
\hline
\end{tabular}

\subsection{Statistical Analysis}

Statistical analysis was performed using GENSTAT 18th Edition with significant differences assessed by two-way analysis of variance (ANOVA) and means compared using Tukey's test. All of the results were expressed as a mean \pm standard errors, and $p \leq 0.05$ was considered statistically significant.

\section{Results}

\section{1. $p H$ in Leachates}

The temporal changes of $\mathrm{pH}$ in the leachate of soil columns under different treatments are shown in Figure 1. The leachate $\mathrm{pH}$ in control was relatively steady over the leaching period, ranging from 5.79 to 6.85. MF addition had no significant influence on leachate $\mathrm{pH}$, but it markedly decreased with CF. At last, the CF treatment had lowered the leachate $\mathrm{pH}$ by 0.27 units on average, relative to the control (Table $2 ; p<0.05$ ). Furthermore, the leachate $\mathrm{pH}$ increased significantly under WSB alone and combined with fertiliser $(p<0.05)$ by $0.31,0.30$ and 0.32 for sole WSB, CF + WSB and MF + WSB, respectively.

\subsection{Volume of Leachates}

The average volume of leachate from the control and fertiliser-treated soils differed from the application of biochar alone and in combination with fertiliser (Figure 2). Addition of CF or MF alone had no significant effect on leachate volume, despite a limited increase over the control $(p>0.05)$. In the biochar treatments, the average leachate volume declined to $367.5,361.6$ and $361.1 \mathrm{~mL}$ in the WSB alone, CF + WSB and MF + WSB treatments, respectively, relative to the control (396.9 $\mathrm{mL})$ (Table 2). 


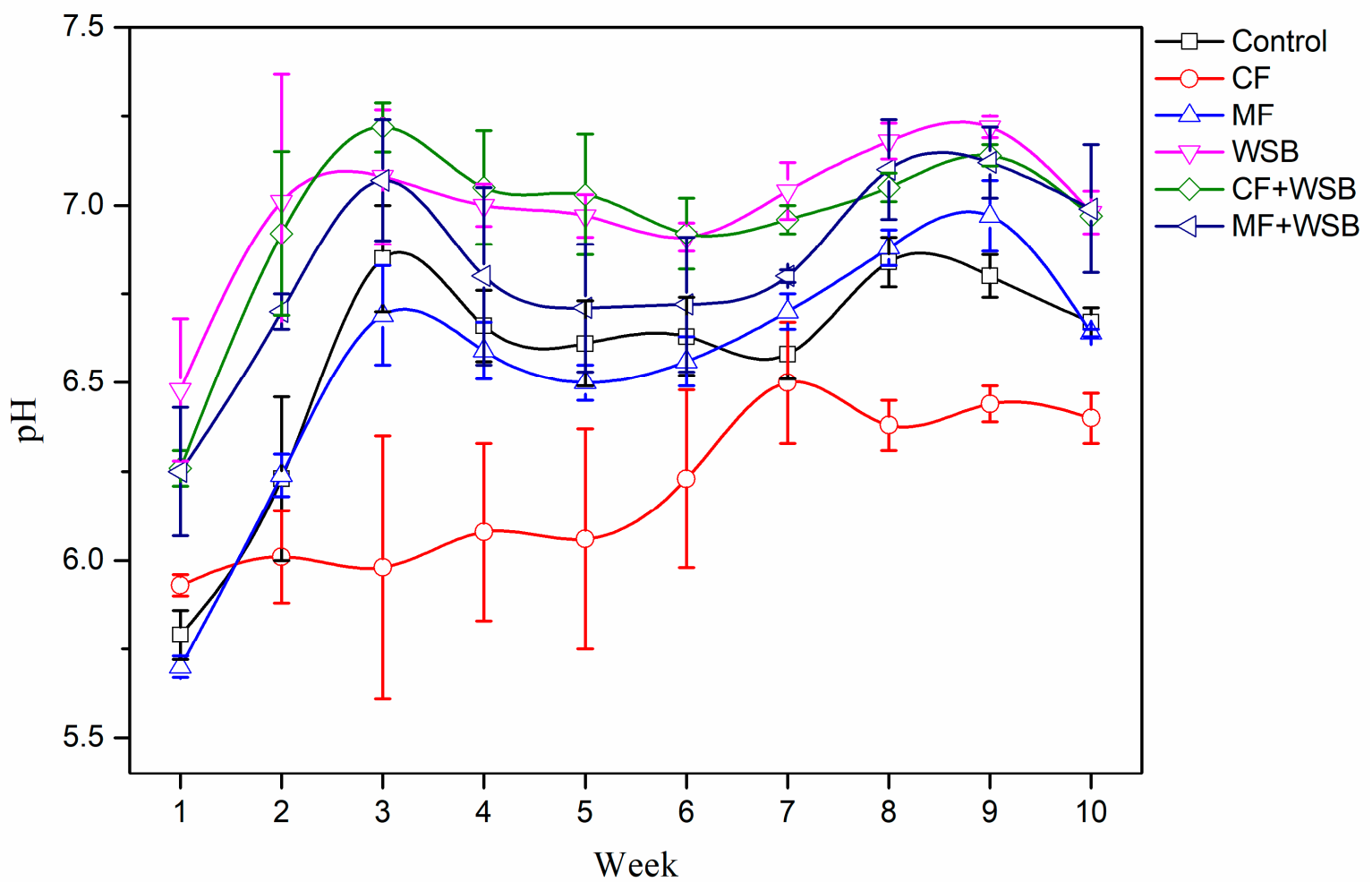

Figure 1. Temporal changes of $\mathrm{pH}$ in the leachate of lysimeters. Data are average values and standard deviations. $\mathrm{CF}=$ chemical fertiliser; $\mathrm{MF}=$ mineral fertiliser; $\mathrm{WSB}=$ wheat straw biochar.

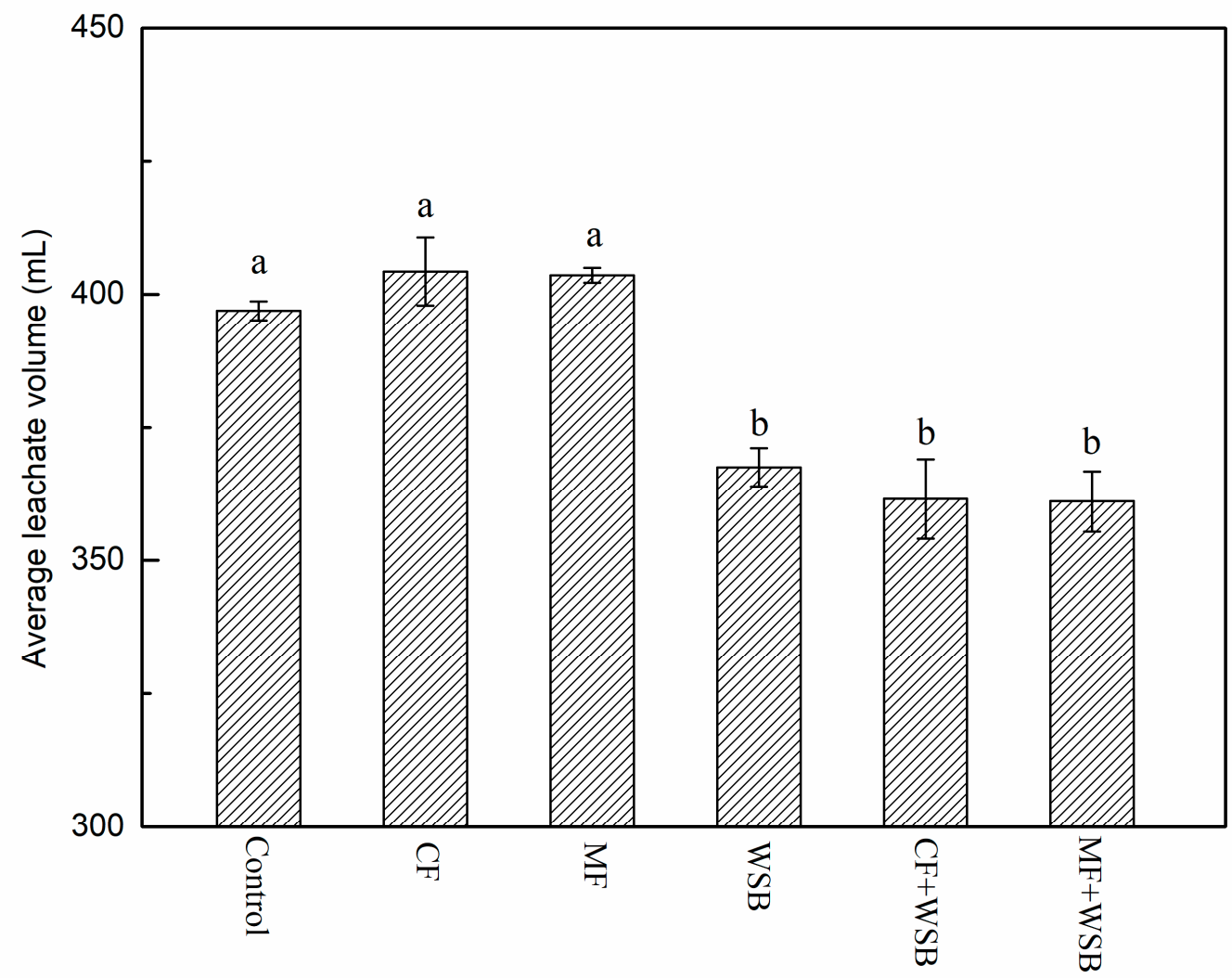

Figure 2. Average volume of leachate per lysimeter. $\mathrm{CF}=$ chemical fertiliser; $\mathrm{MF}=$ mineral fertiliser; $\mathrm{WSB}=\mathrm{wheat}$ straw biochar. Different letter (s) indicate significant differences between treatments $(p<0.05)$. 


\subsection{Nutrients in Leachates}

The amount of leachate nutrients $\left(\mathrm{NH}_{4}{ }^{+}, \mathrm{NO}_{3}{ }^{-}, \mathrm{P}\right.$ and $\left.\mathrm{K}\right)$ differed in the biochar and fertiliser-treated soils, relative to the unamended control. Figure 3a shows the changes in cumulative $\mathrm{NH}_{4}{ }^{+}$losses from the soil column. Compared with unamended soil, the application of $\mathrm{CF}$ or MF increased the cumulative $\mathrm{NH}_{4}{ }^{+}$content in leachate, whereas biochar alone (WSB) had no significant effect on $\mathrm{NH}_{4}{ }^{+}$leaching. Biochar combined with $\mathrm{CF}(\mathrm{CF}+\mathrm{WSB})$ markedly increased $\mathrm{NH}_{4}{ }^{+}$leaching, whereas biochar with MF (MF + WSB) decreased $\mathrm{NH}_{4}{ }^{+}$leaching (by $9.4 \%$ relative to biochar alone).
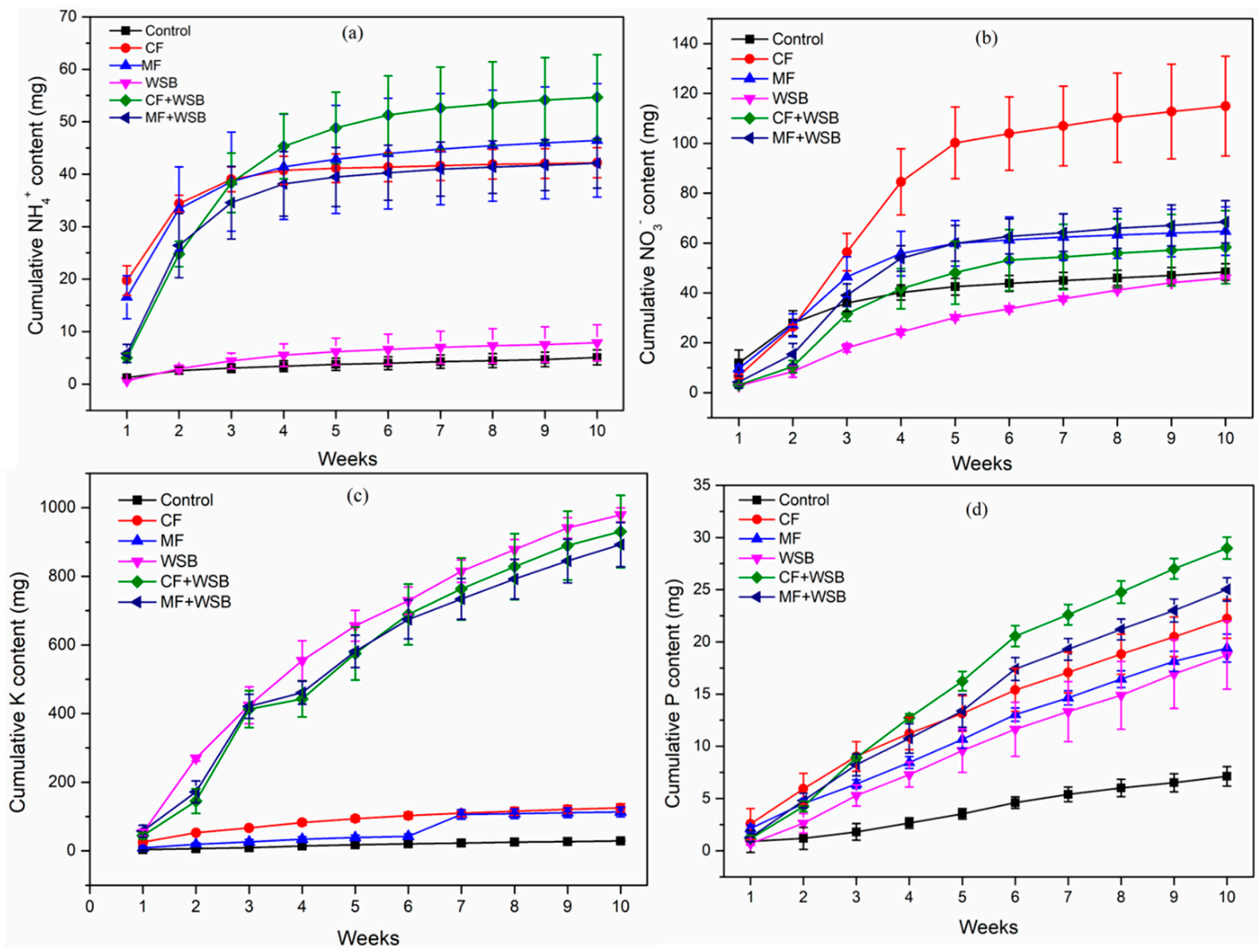

Figure 3. Cumulative amounts of ammonium (a), nitrate (b), potassium (c) and phosphate (d) in the leachates from biochar and fertiliser amended soil and the control soil. $\mathrm{CF}=$ chemical fertiliser; $\mathrm{MF}=$ mineral fertiliser; $\mathrm{WSB}=$ wheat straw biochar.

Figure $3 \mathrm{~b}$ shows the changes in cumulative $\mathrm{NO}_{3}{ }^{-}$losses from the soil column. The $\mathrm{CF}$ and MF treatments increased $\mathrm{NO}_{3}{ }^{-}$leaching, more so in the CF-treated soil than the MF-treated soil. Addition of biochar alone reduced $\mathrm{NO}_{3}{ }^{-}-\mathrm{N}$ leaching in the first six weeks of growth, but no difference was observed from weeks 7 to 10 compared with the control. Biochar significantly reduced the cumulative $\mathrm{NO}_{3}{ }^{-}-\mathrm{N}$ leaching from the CF-treated soil (58.4 mg or $49.2 \%$, relative to the CF treatment), but not the MF-treated soil.

Figure $3 \mathrm{c}$ shows the amount of cumulative $\mathrm{K}$ in the leachate under the different treatments having interaction of biochar $\mathrm{x}$ fertiliser (Table 2). The total cumulative amount of $\mathrm{K}$ in the $\mathrm{CF}$ and MF treatments was relatively low and did not exceed $150 \mathrm{mg}$. However, the cumulative K released from WSB-, CF + WSB- and MF + WSB-treated soils increased sharply during the experiment, to almost 33 times more than the control. Therefore, it was not surprising that $\mathrm{K}$ leaching increased in the CF + WSB and MF + WSB treatments. 
The biochar effect on the leaching of $P$ from fertilised soil was significant (Figure 3d). When biochar was combined with either CF or MF, P leaching increased by about $30.6 \%$ and $28.9 \%$, relative to the sole CF or MF treatments, respectively.

\subsection{Retention of Nutrients in the Soils after Leaching Events}

Table 3 lists the concentration of nutrients retained in each treatment after leaching events in the lysimeter experiment. For $\mathrm{N}$, irrespective of biochar, application of $\mathrm{CF}$ or MF only had a significant effect on $\mathrm{NH}_{4}{ }^{+}-\mathrm{N}$ concentration, relative to the control (Tables 2 and 3). In contrast, the presence of biochar significantly increased $\mathrm{NH}_{4}{ }^{+}-\mathrm{N}, \mathrm{NO}_{3}{ }^{-}-$ $\mathrm{N}$ and total $\mathrm{N}$ concentrations in soil. In the $\mathrm{CF}+\mathrm{WSB}$ treatment, more $\mathrm{NH}_{4}{ }^{+}-\mathrm{N}$ was retained in soil relative to the control. This is also true for the MF + WSB treatment where the $\mathrm{NH}_{4}{ }^{+}-\mathrm{N}$ concentration increased than all other treatments (Table 3). The $\mathrm{NO}_{3}-\mathrm{N}$ concentration in soil was increased in WSB alone compared with other treatments.

The concentration of available $P$ in the soil increased with the sole application of $\mathrm{CF}$ or MF relative to the control, although the total $\mathrm{P}$ concentration remained similar (Table 3). The WSB significantly increased both available and total $\mathrm{P}$ in soil when applied alone or combined with CF + WSB and MF + WSB. The increase in the total P concentration was $26.4 \%$ and $57.2 \%$ in the CF + WSB- and MF + WSB-treated soil, respectively.

Similarly, total $\mathrm{K}$ retained in the soil increased slightly with $\mathrm{CF}$ or MF application. In the CF + WSB treatment, the amount of total K increased significantly, relative to the $\mathrm{CF}$ treatment, from $270.4 \mathrm{mg} / \mathrm{kg}$ to $279.5 \mathrm{mg} / \mathrm{kg}$, with a similar response observed in the MF + WSB treatment relative to the MF treatment. Similar trends were observed for total $\mathrm{P}$ and $\mathrm{K}$ in the combined biochar/fertiliser treatments: the CF + WSB and MF + WSB treatments retained more nutrients, but more than the control treatment.

\subsection{Nutrient Uptake and Plant Growth}

Shoot nutrient uptake was evaluated by measuring nutrient concentration in shoots at harvest (Table 4). The MF treatment reduced shoot $\mathrm{N}$ uptake relative to control but not differed with $\mathrm{CF}$, whereas sole biochar addition significantly increased shoot $\mathrm{N}$ uptake than control or fertiliser alone. The combined application of biochar and fertiliser increased shoot $\mathrm{N}$ uptake over control or fertiliser alone but did not differ with biochar alone. Sole fertiliser (CF or MF) application did not affect shoot $\mathrm{P}$ and $\mathrm{K}$ uptakes, apart from the $\mathrm{CF}$ treatment where shoot $\mathrm{P}$ uptake increased 2.4-fold, relative to the control. Biochar significantly increased shoot $\mathrm{P}$ and $\mathrm{K}$ uptakes, relative to the control, more when combining with $\mathrm{CF}$ or MF. For instance, the CF + WSB treatment increased plant K uptake by $53.2 \%$, relative to the CF treatment.

Table 4. Shoot nutrients (N, P, K) uptake of wheat for the fertiliser, biochar and their interactions. Values of parameters are shown as means \pm standard errors. Different letters indicate significant differences between treatments $(p<0.05)$.

\begin{tabular}{|c|c|c|c|}
\hline Treatment & $\begin{array}{c}\mathrm{N} \\
(\mathrm{mg} \mathrm{pot}-1)\end{array}$ & $\begin{array}{c}P \\
(\mathrm{mg} \mathrm{pot}-1)\end{array}$ & $\begin{array}{c}\mathrm{K} \\
(\mathrm{mg} \mathrm{pot}-1)\end{array}$ \\
\hline Control & $9.97 \pm 0.79 b$ & $0.72 \pm 0.14 \mathrm{~d}$ & $12.77 \pm 1.71 \mathrm{~d}$ \\
\hline CF & $8.26 \pm 1.69 \mathrm{bc}$ & $2.46 \pm 0.15 b$ & $18.19 \pm 2.93 \mathrm{~cd}$ \\
\hline $\mathrm{MF}$ & $6.97 \pm 0.51 c$ & $1.13 \pm 0.17 \mathrm{~cd}$ & $11.93 \pm 0.22 \mathrm{~d}$ \\
\hline WSB & $12.37 \pm 0.16 \mathrm{a}$ & $2.60 \pm 0.26 \mathrm{ab}$ & $26.07 \pm 1.76 \mathrm{ab}$ \\
\hline $\mathrm{CF}+\mathrm{WSB}$ & $11.41 \pm 0.13 \mathrm{a}$ & $3.24 \pm 0.49 \mathrm{a}$ & $27.87 \pm 2.20 \mathrm{a}$ \\
\hline $\mathrm{MF}+\mathrm{WSB}$ & $12.02 \pm 1.08 \mathrm{a}$ & $2.94 \pm 0.31 \mathrm{ab}$ & $25.74 \pm 0.99 \mathrm{ab}$ \\
\hline Biochar & $<0.001$ & $<0.001$ & $<0.001$ \\
\hline Fertiliser & 0.038 & $<0.001$ & 0.006 \\
\hline Biochar $\times$ Fertiliser & 0.061 & 0.016 & 0.566 \\
\hline
\end{tabular}

Dry weights of shoot and root are presented in Figure 4. Application of CF or MF alone did not alter shoot or root biomass, relative to the control. However, the CF + WSB 
treatment produced more shoot dry weight $(0.517 \mathrm{~g} / \mathrm{pot})$ than the CF alone treatment (0.377 g/pot). Similarly, the MF + WSB treatment increased shoot biomass by $65.7 \%$ compared with the MF alone treatment. None of the treatment significantly increased root weight, except for the CF + WSB treatment that significantly increased root biomass $(1.65 \mathrm{~g} / \mathrm{pot})$ relative to the control $(0.440 \mathrm{~g} / \mathrm{pot})$.
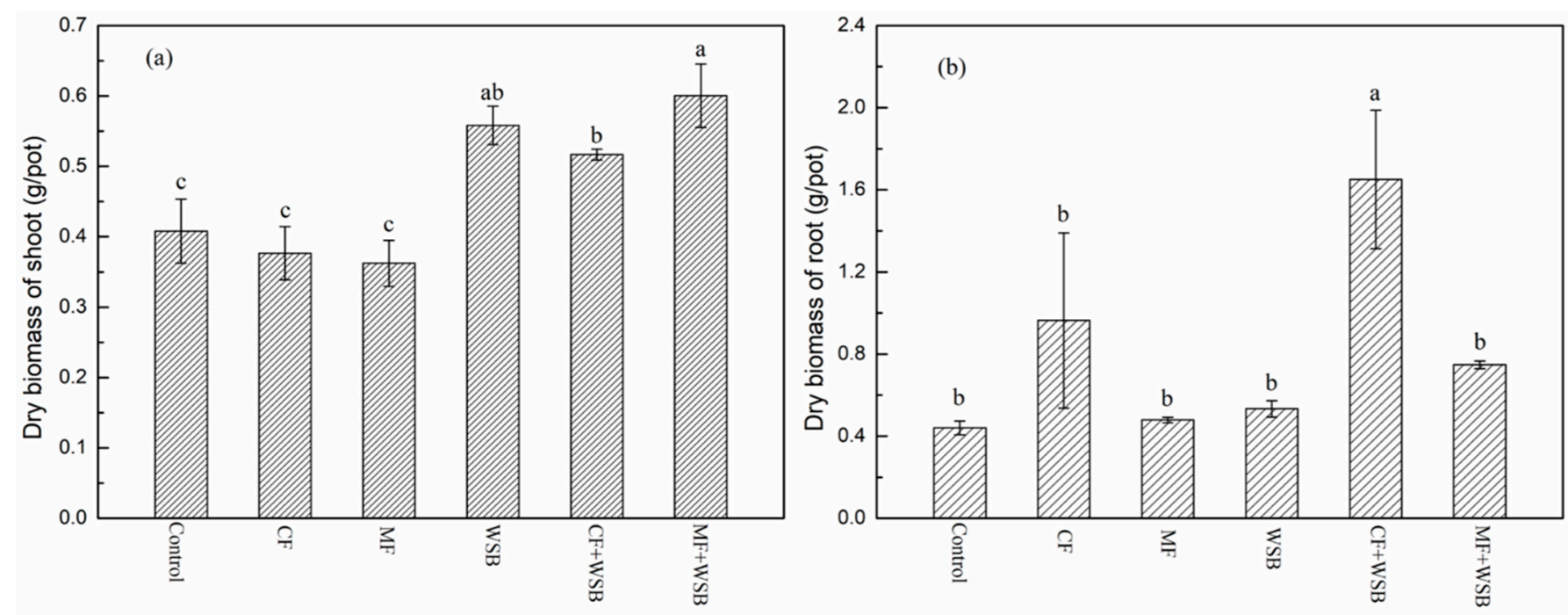

Figure 4. Shoot (a) and root (b) biomass of wheat affected by fertiliser and biochar nutrients retained in the soil at the end of the leaching experiment. $\mathrm{CF}=$ chemical fertiliser; $\mathrm{MF}=$ mineral fertiliser; WSB $=$ wheat straw biochar. Different letter ( $\mathrm{s}$ ) indicate significant differences between treatments $(p<0.05)$.

\section{Discussion}

\subsection{Effect of Fertiliser and Biochar Amendment on $\mathrm{pH}$ and Volume of Leachate}

The fertiliser and biochar treatments significantly differed in terms of $\mathrm{pH}$ and volume of leachate. The $\mathrm{CF}$ treatment significantly reduced the $\mathrm{pH}$ in leachate, which agrees with the findings of Hati et al. [27] who reported a decline in soil $\mathrm{pH}$ with the application of ammonium fertiliser and could be due to the fast release of $\mathrm{NH}_{4}{ }^{+}$. Similar results have been reported by Heinze et al. [28] and Liu et al. [29] indicating a decrease in $\mathrm{pH}$ due to the application of chemical fertiliser than organic fertiliser. When chemical fertiliser is applied to the soil, oxidation of the released $\mathrm{NH}_{4}+$ could produce $\mathrm{H}^{+}$ions and thus reduce soil $\mathrm{pH}$ and leachate $\mathrm{pH}$ [30]. The MF treatment had little or no influence on leachate $\mathrm{pH}$, which could be attributed to the slow release of nutrients from MF.

Biochar amendment can be used with $\mathrm{NH}_{4}{ }^{+}$fertiliser to minimise the soil $\mathrm{pH}$ decrease. The mechanism behind this that biochars are alkaline has a buffering capacity to neutralise soil acidity [31,32]. In this study, biochar application significantly increased $(p<0.05)$ leachate $\mathrm{pH}$, relative to the control and fertiliser only treatments (Figure 1). For the WSBtreated soils, more mineral ions, such as $\mathrm{Ca}^{2+}, \mathrm{K}^{+}$, and $\mathrm{Mg}^{2+}$, were dissolved and leached in water, which was supported by the higher electrical conductivity in the leachate of those treatments (data not shown).

The CF and MF treatments did not affect leachate volume $(p>0.05)$. However, the biochar treatments significantly reduced the average volume, which implies that biochar increased soil WHC. A study has have shown that soil water retention is generally dependent on soil bulk density, surface area, pore-size distribution and aggregation [33]. An increase in organic matter content could also retain more moisture in the soil [33,34]. Increases in soil WHC could enhance nutrient availability (e.g., N, P, and K) and reduce irrigation requirements and nutrient leaching, especially in sandy soils [35]. 


\subsection{Effect of Fertiliser and Biochar Amendment on Nutrient Leaching}

The effect of biochar on nutrient leaching was highly variable and depended on the fertiliser and biochar application (Figure 3). The wheat straw biochar amendment did not affect $\mathrm{NH}_{4}{ }^{+}$leaching in the MF-treated soil and even increased the cumulative $\mathrm{NH}_{4}{ }^{+}$ concentration in the CF + WSB treatment, which indicates that WSB has negligible ability to absorb $\mathrm{NH}_{4}{ }^{+}$. Williams and Reed [36] and Singh et al. [37] reported that biochar prepared at low-temperature $\left(<600^{\circ} \mathrm{C}\right)$ could not remove ammonium, as we found with biochar produced at $550{ }^{\circ} \mathrm{C}$. The lack of effect of $\mathrm{WSB}$ on $\mathrm{NH}_{4}{ }^{+}$leaching could also be related to the contribution of its intrinsic $\mathrm{N}$.

It was expected that $\mathrm{NH}_{4}{ }^{+}$ions would bind with acid functional groups or cationic species on the surface of the biochar via cation exchange [38,39], and that $\mathrm{NH}_{4}{ }^{+}$absorption capacity would be limited and depend on feedstocks and the pyrolysis technology [40]. Thus, the $\mathrm{NH}_{4}{ }^{+}-\mathrm{N}$ content in the CF-treated soil was readily released, and the amount is more than the maximum adsorption capacity of WSB, resulting in a substantial amount of $\mathrm{NH}_{4}{ }^{+}$leaching.

Biochar soil amendment to CF-treated soil (CF + WSB) reduced the amount of $\mathrm{NO}_{3}{ }^{-}-\mathrm{N}$ leached from the soil by $49.2 \%$, relative to the CF treatment. However, the MF + WSB treatment had no significant effect on $\mathrm{NO}_{3}{ }^{-}-\mathrm{N}$ leaching, relative to the MF treatment (Figure $3 \mathrm{~b}$ ). The results show that $\mathrm{NO}_{3}{ }^{-}-\mathrm{N}$ leaching varied greatly with fertiliser type. Multiple mechanisms could be responsible for $\mathrm{NO}_{3}{ }^{-}-\mathrm{N}$ leaching in the biochar-amended soil, including (i) nitrate adsorption ability of the biochar, (ii) rate of $\mathrm{N}$ nitrification and denitrification, (iii) enhanced microbial respiration and mineralisation of organic $\mathrm{N}$ affected by biochar and (iv) increased soil water-holding capacity [32,41,42]. Further studies are needed to reveal the governing mechanisms under different biochar and soil types as well as fertiliser management.

For $\mathrm{K}$ content in the leachate, biochar addition significantly increased $\mathrm{K}$ leaching from the fertilised soils throughout the experiment, indicating a substantial fraction of initial $\mathrm{K}$ in the biochar was mobile and easily leached. The results are consistent with those of Laird et al. [42], where biochar addition increased the amount of $\mathrm{Ca}, \mathrm{Mg}$ and $\mathrm{K}$ in weekly leachate. It should be noted that enhanced $\mathrm{K}$ leaching occurred in both the WSB alone and WSB combined with fertiliser treatments, despite lower levels of $\mathrm{K}$ leaching in the control and fertiliser only treatments (Figure 3c). The mechanisms responsible for this synergistic effect could be due to improved physical properties of soils, resulting in nutrient availability and consequently leaching, especially cations such as $\mathrm{K}^{+}, \mathrm{Na}^{+}$and $\mathrm{Ca}^{2+}$ [21]. Agegnehu et al. [43] reported an increase in available $\mathrm{K}, \mathrm{Mg}$ and $\mathrm{Al}$ contents in soils with biochar and compost amendment, and they attributed this positive effect to the enhanced CEC and intrinsic elemental nutrients of biochar. Schulz and Glaser [21] reported that biochar increased plant-available $\mathrm{K}$ but had no effect on other cations, and attributed this effect to the change in $\mathrm{pH}$, which affected nutrient availability. This is consistent with our findings on leachate $\mathrm{pH}$, which increased with WSB addition (Figure 1).

The WSB combined with fertiliser treatments had higher total $\mathrm{P}$ concentrations in leachate than the other treatments. This is consistent with the findings of Yao et al. [44], who reported that biochar had various effects on nutrient leaching. The varied effect of WSB biochar on P leaching could be due to: (i) the WSB had high water-extractable P contentTroy et al. [17] reported that pig manure biochar increased P leaching due to dissolved reactive $\mathrm{P}$ content-and (ii) the WSB had a low phosphate adsorption capacity. Several studies have demonstrated that feedstocks and intrinsic metal elements (e.g., $\mathrm{Mg}, \mathrm{Al}$ and Fe) play an important role in phosphate recovery $[45,46]$. Yao et al. [47] found that biochar prepared from $\mathrm{Mg}$-enriched tomato tissues had a remarkable phosphate sorption capacity, as did biochar impregnated with lanthanum [48]. In our study, we did not measure $\mathrm{Mg}$ in the biochar. Further investigations are needed to reveal the underlying mechanisms of nutrient retention and leaching in biochar-amended soils. 


\subsection{Effect of Fertiliser and Biochar Amendment on Nutrient Retention in Soils}

For total N, the CF and MF treatments did not significantly differ from at the end of the leaching experiment, relative to the control, indicating that rapid $\mathrm{N}$ leaching losses occurred in the fertilised sandy soil. In contrast, WSB combined with fertiliser treatments enhanced total $\mathrm{N}$ retention after ten weeks of leaching events, relative to their respective fertiliser only treatment (Table 4). Other studies have reported similar findings of biochar enhancing fertiliser $\mathrm{N}$ retention $[14,16,22]$.

Interestingly, biochar effects on the retention of $\mathrm{NH}_{4}{ }^{+}$in soil were not consistent, having interaction between biochar $x$ fertiliser (Table 3). Biochar increased $\mathrm{NH}_{4}{ }^{+}-\mathrm{N}$ concentrations in CF- and MF-treated soils, but had little or no effect on $\mathrm{NO}_{3}{ }^{-}$concentrations, except for those increased with WSB alone (Table 3). Similarly, Zheng et al. [22] found that biochar addition led to more $\mathrm{NH}_{4}{ }^{+}-\mathrm{N}$ and less $\mathrm{NO}_{3}{ }^{-}-\mathrm{N}$ retained in $\mathrm{NH}_{4}{ }^{+}-\mathrm{N}$-fertilised soil, whereas an opposite occurred in $\mathrm{NO}_{3}{ }^{-}-\mathrm{N}$-fertilised soil. Biochar application to soil may manipulate the $\mathrm{N}$ cycle, which is responsible for $\mathrm{N}$ distribution $[39,49]$. Thus, it can be concluded that biochar application possibly enhanced nitrification.

Wheat straw biochar application increased total $\mathrm{K}$ and $\mathrm{P}$ concentrations in the soil, relative to fertiliser application alone. However, as noted above, the increased accumulation of $\mathrm{P}$ and $\mathrm{K}$ in the leachate with biochar addition reduced $\mathrm{P}$ leaching. Contradictory results obtained in this experiment may be due to the high input of $\mathrm{P}$ and $\mathrm{K}$ derived from biochar. Several studies have indicated that biochar could be used as a P and K fertiliser due to its high concentrations $[14,50,51]$. The total amount of $\mathrm{K}$ and $\mathrm{P}$ in the soil increased significantly with biochar alone, relative to the control soil, indicating a net release of $\mathrm{K}$ and $\mathrm{P}$ from WSB. Finally, the results obtained from this investigation suggest that the addition of biochar either alone or with fertiliser to soils could increase the capacity of soils to retain nutrients and thereby improve nutrient use efficiency. The long-term interactions of biochar and fertiliser in amended soils should be investigated further.

\subsection{Effect of Fertiliser and Biochar Amendment on Shoot Nutrient Uptake and Plant Growth}

In this study, all fertiliser amendments had no significant effect on plant $\mathrm{N}$ uptake over control, despite higher $\mathrm{N}$ uptake in the biochar alone or biochar combined with fertiliser treatments, which was supported by Solaiman et al. [13]. However, these data were not reported by Sun et al. [52], where N uptake of the cultivated crop with either $50 \%$ or $100 \%$ fertiliser did not change with the addition of biochar. Nitrogen availability is generally the main factor for $\mathrm{N}$ uptake by plants. Therefore, based on results of our study, it is possible that biochar application enhances $\mathrm{N}$ supply to the plants.

Similar to plant $\mathrm{N}$ uptake, WSB also increased wheat $\mathrm{P}$ and $\mathrm{K}$ uptakes over control where P uptake was influenced by biochar $\mathrm{x}$ fertiliser interaction (Table 4). The mechanisms responsible for the positive effect of biochar on nutrient uptake have been proposed as the direct nutrient supply by biochar and improvements in soil physical properties, such as $\mathrm{pH}$, exchangeable cations and WHC, resulting in benefits for nutrient retention $[33,53]$. Solaiman et al. [13] suggested that biochar has a beneficial effect on mycorrhizal colonisation by increasing the surface area for microorganisms, thereby enhancing $\mathrm{N}$ and $\mathrm{P}$ uptake. The biochar used in our study contained high levels of plant-available nutrients, especially $\mathrm{P}$ and $\mathrm{K}$ (Table 4), which may have improved nutrient uptake in all fertiliser treatments with biochar. This would explain the enhanced wheat growth in biochar-amended soils.

We found no statistically significant effects of CF or MF on wheat growth, which may be the result of the high rates of nutrient loss observed in the leaching experiment, which depleted soil fertility in fertiliser-amended soils. In contrast, biochar increased wheat growth, mainly shoot DW, which was attributed to higher nutrient supply from WSB. In general, crop residue-derived biochar has higher ash and nutrient contents than biochar prepared from woody material [54,55]. Alburquerque et al. [56] reported that biochar with a higher percentage of ash, including wheat straw biochar, increased sunflower growth more than other biochar, such as pine woodchip biochar. 


\section{Conclusions}

The results of our study indicate that wheat straw biochar (WSB) enhances both nutrient leaching and retention in soils amended with CF or MF fertilisers. Application of WSB decreased $\mathrm{NH}_{4}{ }^{+}$in MF-treated soil and $\mathrm{NO}_{3}{ }^{-}$in $\mathrm{CF}$-treated soil, whereas $\mathrm{K}$ and $\mathrm{P}$ leaching increased due to intrinsic nutrients released from WSB. The analysis of residual nutrients at the end of the leaching experiment showed that biochar amendment with fertiliser increased N, P and K retention relative to fertiliser alone. Pot experiments demonstrated that biochar enhanced N, P and K uptake in wheat shoots as well as shoot growth when combined with fertilisers, which may be due to direct nutrient supply by biochar and its higher nutrient availability. However, none of the treatments affected root growth Therefore, for future studies the properties of biochar and fertiliser should be considered before amending soil.

Author Contributions: Conceptualisation, C.H. and Z.M.S.; methodology, C.H. and Z.M.S.; investigation, C.H.; data analysis, C.H.; resources, Z.M.S.; writing-original draft preparation, C.H.; writing-review and editing, Z.M.S.; K.H.M.S.; X.S.; L.W.; P.S.; supervision, Z.M.S. All authors have read and agreed to the published version of the manuscript.

Funding: This research received no external funding.

Institutional Review Board Statement: Not Applicable.

Informed Consent Statement: Not Applicable.

Data Availability Statement: Not Applicable.

Acknowledgments: The Science and Technology Department of Jiangsu Province, China (BK20161497) supported for Cheng Huang's visit to The University of Western Australia.

Conflicts of Interest: The authors declare no conflict of interest.

\section{References}

1. Stewart, W.M.; Dibb, D.W.; Johnston, A.E.; Smyth, T.J. The contribution of commercial fertilizer nutrients to food production. Agron. J. 2005, 97, 1-6. [CrossRef]

2. Ju, X.; Kou, C.; Christie, P.; Dou, Z.; Zhang, F. Changes in the soil environment from excessive application of fertilizers and manures to two contrasting intensive cropping systems on the North China Plain. Environ. Pollut. 2007, 145, 497-506. [CrossRef] [PubMed]

3. Sebilo, M.; Mayer, B.; Nicolardot, B.; Pinay, G.; Mariotti, A. Long-term fate of nitrate fertilizer in agricultural soils. Proc. Natl. Acad. Sci. USA 2013, 110, 18185-18189. [CrossRef] [PubMed]

4. Mahvi, A.H.; Nouri, J.; Babaei, A.A.; Nabizadeh, R. Agricultural activities impact on groundwater nitrate pollution. Int. J. Environ. Sci. Technol. 2005, 2, 41-47. [CrossRef]

5. Bennett, E.M.; Carpenter, S.R.; Caraco, N.F. Human impact on erodable phosphorus and eutrophication: A global perspective increasing accumulation of phosphorus in soil threatens rivers, lakes, and coastal oceans with eutrophication. BioScience 2001, 51, 227-234. [CrossRef]

6. Hass, A.; Gonzalez, J.M.; Lima, I.M.; Godwin, H.W.; Halvorson, J.J.; Boyer, D.G. Chicken manure biochar as liming and nutrient source for acid appalachian soil. J. Environ. Qual. 2012, 41, 1096-1106. [CrossRef] [PubMed]

7. Uzoma, K.C.; Inoue, M.; Andry, H.; Fujimaki, H.; Zahoor, A.; Nishihara, E. Effect of cow manure biochar on maize productivity under sandy soil condition. Soil Use Manag. 2011, 27, 205-212. [CrossRef]

8. Jiang, T.-Y.; Jiang, J.; Xu, R.-K.; Li, Z. Adsorption of $\mathrm{Pb}(\mathrm{II})$ on variable charge soils amended with rice-straw derived biochar. Chemosphere 2012, 89, 249-256. [CrossRef] [PubMed]

9. Hossain, M.K.; Strezov, V.; McCormick, L.; Nelson, P.F. Wastewater sludge and sludge biochar addition to soils for biomass production from Hyparrhenia hirta. Ecol. Eng. 2015, 82, 345-348. [CrossRef]

10. Méndez, A.; Gómez, A.; Paz-Ferreiro, J.; Gascó, G. Effects of sewage sludge biochar on plant metal availability after application to a Mediterranean soil. Chemosphere 2012, 89, 1354-1359. [CrossRef] [PubMed]

11. Qambrani, N.A.; Rahman, M.; Won, S.; Shim, S.; Ra, C. Biochar properties and eco-friendly applications for climate change mitigation, waste management, and wastewater treatment: A review. Renew. Sustain. Energy Rev. 2017, 79, 255-273. [CrossRef]

12. Blackwell, P.; Joseph, S.; Munroe, P.; Anawar, H.M.; Storer, P.; Gilkes, R.; Solaiman, Z.M. Influences of biochar and biochar-mineral complex on mycorrhizal colonisation and nutrition of wheat and sorghum. Pedosphere 2015, 25, 686-695. [CrossRef]

13. Solaiman, Z.M.; Blackwell, P.; Abbott, L.; Storer, P. Direct and residual effect of biochar application on mycorrhizal root colonisation, growth and nutrition of wheat. Soil Res. 2010, 48, 546-554. [CrossRef] 
14. Lehmann, J.; da Silva, J.P.; Steiner, C.; Nehls, T.; Zech, W.; Glaser, B. Nutrient availability and leaching in an archaeological Anthrosol and a Ferralsol of the Central Amazon basin: Fertilizer, manure and charcoal amendments. Plant Soil 2003, 249, 343-357. [CrossRef]

15. Ding, Y.; Liu, Y.-X.; Wu, W.-X.; Shi, D.-Z.; Yang, M.; Zhong, Z.-K. Evaluation of biochar effects on nitrogen retention and leaching in multi-layered soil columns. Water Air Soil Pollut. 2010, 213, 47-55. [CrossRef]

16. Zhao, X.; Yan, X.; Wang, S.; Xing, G.; Zhou, Y. Effects of the addition of rice-straw-based biochar on leaching and retention of fertilizer N in highly fertilized cropland soils. Soil Sci. Plant Nutr. 2013, 59, 771-782. [CrossRef]

17. Troy, S.M.; Lawlor, P.G.; Flynn, C.J.O.; Healy, M.G. The impact of biochar addition on nutrient leaching and soil properties from tillage soil amended with pig manure. Water Air Soil Pollut. 2014, 225, 1-15. [CrossRef]

18. Faloye, O.; Alatise, M.; Ajayi, A.; Ewulo, B. Synergistic effects of biochar and inorganic fertiliser on maize (zea mays) yield in an alfisol under drip irrigation. Soil Tillage Res. 2017, 174, 214-220. [CrossRef]

19. Iqbal, H.; Garcia-Perez, M.; Flury, M. Effect of biochar on leaching of organic carbon, nitrogen, and phosphorus from compost in bioretention systems. Sci. Total Environ. 2015, 521, 37-45. [CrossRef]

20. Madiba, O.F.; Solaiman, Z.M.; Carson, J.K.; Murphy, D.V. Biochar increases availability and uptake of phosphorus to wheat under leaching conditions. Biol. Fertil. Soils 2016, 52, 439-446. [CrossRef]

21. Schulz, H.; Glaser, B. Effects of biochar compared to organic and inorganic fertilizers on soil quality and plant growth in a greenhouse experiment. J. Plant Nutr. Soil Sci. 2012, 175, 410-422. [CrossRef]

22. Zheng, H.; Wang, Z.; Deng, X.; Herbert, S.; Xing, B. Impacts of adding biochar on nitrogen retention and bioavailability in agricultural soil. Geoderma 2013, 206, 32-39. [CrossRef]

23. Solaiman, Z.M.; Murphy, D.; Abbott, L. Biochars influence seed germination and early growth of seedlings. Plant Soil 2012, 353, 273-287. [CrossRef]

24. Krom, M.D. Spectrophotometric determination of ammonia: A study of a modified Berthelot reaction using salicylate and dichloroisocyanurate. Analyst 1980, 105, 305-316. [CrossRef]

25. Kamphake, L.; Hannah, S.; Cohen, J. Automated analysis for nitrate by hydrazine reduction. Water Res. 1967, 1, 205-216. [CrossRef]

26. Murphy, J.; Riley, J.P. A modified single solution method for the determination of phosphate in natural waters. Anal. Chim. Acta 1962, 27, 31-36. [CrossRef]

27. Hati, K.M.; Swarup, A.; Mishra, B.; Manna, M.; Wanjari, R.; Mandal, K.; Misra, A. Impact of long-term application of fertilizer, manure and lime under intensive cropping on physical properties and organic carbon content of an Alfisol. Geoderma 2008, 148, 173-179. [CrossRef]

28. Heinze, S.; Raupp, J.; Joergensen, R.G. Effects of fertilizer and spatial heterogeneity in soil pH on microbial biomass indices in a long-term field trial of organic agriculture. Plant Soil 2010, 328, 203-215. [CrossRef]

29. Liu, E.; Yan, C.; Mei, X.; He, W.; Bing, S.H.; Ding, L.; Liu, Q.; Liu, S.; Fan, T. Long-term effect of chemical fertilizer, straw, and manure on soil chemical and biological properties in northwest China. Geoderma 2010, 158, 173-180. [CrossRef]

30. Magdoff, F.; Lanyon, L.; Liebhardt, B. Nutrient cycling, transformations, and flows: Implications for a more sustainable agriculture. In Advances in Agronomy; Elsevier: Amsterdam, The Netherlands, 1997; pp. 1-73.

31. Xu, N.; Tan, G.; Wang, H.; Gai, X. Effect of biochar additions to soil on nitrogen leaching, microbial biomass and bacterial community structure. Eur. J. Soil Biol. 2016, 74, 1-8. [CrossRef]

32. Sun, H.; Lu, H.; Chu, L.; Shao, H.; Shi, W. Biochar applied with appropriate rates can reduce N leaching, keep N retention and not increase NH3 volatilization in a coastal saline soil. Sci. Total Environ. 2017, 575, 820-825. [CrossRef] [PubMed]

33. Atkinson, C.J.; Fitzgerald, J.D.; Hipps, N.A. Potential mechanisms for achieving agricultural benefits from biochar application to temperate soils: A review. Plant. Soil 2010, 337, 1-18. [CrossRef]

34. Madsen, H.B.; Platou, S.W. Land use planning in Denmark. Hydrol. Res. 1983, 14, 267-276. [CrossRef]

35. Major, J.; Steiner, C.; Downie, A.; Lehmann, J. Biochar Effects on Nutrient Leaching. Biochar for Environmental Management. Sci. Technol. 2009, 271-282. Available online: https://www.researchgate.net/publication/221899780_Biochar_effects_on_nutrient_ leaching (accessed on 7 November 2021).

36. Williams, P.; Reed, A. Development of activated carbon pore structure via physical and chemical activation of biomass fibre waste. Biomass Bioenergy 2006, 30, 144-152. [CrossRef]

37. Singh, B.P.; Hatton, B.J.; Singh, B.; Cowie, A.L.; Kathuria, A. Influence of biochars on nitrous oxide emission and nitrogen leaching from two contrasting soils. J. Environ. Qual. 2010, 39, 1224-1235. [CrossRef] [PubMed]

38. Mukherjee, A.; Zimmerman, A. Organic carbon and nutrient release from a range of laboratory-produced biochars and biocharsoil mixtures. Geoderma 2013, 193, 122-130. [CrossRef]

39. Clough, T.J.; Condron, L.M. Biochar and the nitrogen cycle: Introduction. J. Environ. Qual. 2010, 39, 1218-1223. [CrossRef] [PubMed]

40. Taghizadeh-Toosi, A.; Clough, T.J.; Sherlock, R.R.; Condron, L.M. Biochar adsorbed ammonia is bioavailable. Plant Soil 2012, 350, 57-69. [CrossRef]

41. Pratiwi, E.P.A.; Hillary, A.K.; Fukuda, T.; Shinogi, Y. The effects of rice husk char on ammonium, nitrate and phosphate retention and leaching in loamy soil. Geoderma 2016, 277, 61-68. [CrossRef] 
42. Laird, D.; Fleming, P.; Wang, B.; Horton, R.; Karlen, D. Biochar impact on nutrient leaching from a Midwestern agricultural soil. Geoderma 2010, 158, 436-442. [CrossRef]

43. Agegnehu, G.; Bass, A.; Nelson, P.; Muirhead, B.; Wright, G.; Bird, M. Biochar and biochar-compost as soil amendments: Effects on peanut yield, soil properties and greenhouse gas emissions in tropical North Queensland, Australia. Agric. Ecosyst. Environ. 2015, 213, 72-85. [CrossRef]

44. Yao, Y.; Gao, B.; Zhang, M.; Inyang, M.; Zimmerman, A. Effect of biochar amendment on sorption and leaching of nitrate, ammonium, and phosphate in a sandy soil. Chemosphere 2012, 89, 1467-1471. [CrossRef]

45. Chintala, R.; Schumacher, T.E.; McDonald, L.M.; Clay, D.E.; Malo, D.D.; Papiernik, S.K.; Clay, S.A.; Julson, J.L. Phosphorus sorption and availability from biochars and soil/biochar mixtures. CLEAN Soil Air Water 2014, 42, 626-634. [CrossRef]

46. Li, R.; Wang, J.J.; Zhou, B.; Awasthi, M.K.; Ali, A.; Zhang, Z.; Lahori, A.H.; Mahar, A. Recovery of phosphate from aqueous solution by magnesium oxide decorated magnetic biochar and its potential as phosphate-based fertilizer substitute. Bioresour. Technol. 2016, 215, 209-214. [CrossRef]

47. Yao, Y.; Gao, B.; Chen, J.; Yang, L. Engineered biochar reclaiming phosphate from aqueous solutions: Mechanisms and potential application as a slow-release fertilizer. Environ. Sci. Technol. 2013, 47, 8700-8708. [CrossRef]

48. Wang, Z.; Shen, D.; Shen, F.; Li, T. Phosphate adsorption on lanthanum loaded biochar. Chemosphere 2016, 150, 1-7. [CrossRef]

49. Clough, T.J.; Condron, L.M.; Kammann, C.; Muller, C.W. A review of biochar and soil nitrogen dynamics. Agronomy 2013, 3, 275-293. [CrossRef]

50. Wang, T.; Camps-Arbestain, M.; Hedley, M. The fate of phosphorus of ash-rich biochars in a soil-plant system. Plant Soil 2014, 375, 61-74. [CrossRef]

51. Altland, J.E.; Locke, J.C. Effect of biochar type on macronutrient retention and release from soilless substrate. HortScience 2013, 48, 1397-1402. [CrossRef]

52. Sun, Z.; Sänger, A.; Rebensburg, P.; Lentzsch, P.; Wirth, S.; Kaupenjohann, M.; Meyer-Aurich, A. Contrasting effects of biochar on $\mathrm{N}_{2} \mathrm{O}$ emission and $\mathrm{N}$ uptake at different $\mathrm{N}$ fertilizer levels on a temperate sandy loam. Sci. Total Environ. 2017, 578, 557-565. [CrossRef]

53. Walter, R.; Rao, B.K.R. Biochars influence sweet-potato yield and nutrient uptake in tropical Papua New Guinea. J. Plant. Nutr. Soil Sci. 2015, 178, 393-400. [CrossRef]

54. Ahmed, M.B.; Zhou, J.L.; Ngo, H.H.; Guo, W. Insight into biochar properties and its cost analysis. Biomass Bioenergy 2016, 84, 76-86. [CrossRef]

55. Ding, Y.; Liu, Y.; Liu, S.; Li, Z.; Tan, X.; Huang, X.; Zeng, G.; Zhou, L.; Zheng, B. Biochar to improve soil fertility. A review. Agron. Sustain. Dev. 2016, 36, 36. [CrossRef]

56. Alburquerque, J.A.; Calero, J.M.; Barrón, V.; Torrent, J.; Del Campillo, M.C.; Gallardo, A.; Villar, R. Effects of biochars produced from different feedstocks on soil properties and sunflower growth. J. Plant Nutr. Soil Sci. 2014, 177, 16-25. [CrossRef] 